\title{
Beliefs about Learning English as a Second Language Among Native Groups in Rural Sabah, Malaysia
}

\author{
HARIHARAN N.KRISHNASAMY (Corresponding author) \\ Universiti Utara Malaysia, School of Education and Modern Languages, \\ College of Arts and Sciences, Universiti Utara Malaysia, Sintok, Kedah, Malaysia \\ E-mail: hn1084@uum.edu.my \\ ARSAYTHAMBY VELOO \\ Universiti Utara Malaysia, School of Education and Modern Languages, \\ College of Arts and Sciences, Universiti Utara Malaysia, Sintok, Kedah, Malaysia \\ HO FUI LU \\ Universiti Utara Malaysia, School of Education and Modern Languages, \\ College of Arts and Sciences, Universiti Utara Malaysia, Sintok, Kedah, Malaysia
}

Doi:10.7575/aiac.alls.v.4n.2p.39

URL: http://dx.doi.org/10.7575/aiac.alls.v.4n.2p.39
Received: 02/04/2013

Accepted: 01/06/2013

\begin{abstract}
This paper identifies differences between the three ethnic groups, namely, Kadazans/Dusuns, Bajaus, and other minority ethnic groups on the beliefs about learning English as a second language based on the five variables, that is, language aptitude, language learning difficulty, language learning and communicating strategies, nature of language learning as well as learning motivation and expectation. A modified version of Horwitz's (1987) Beliefs about Language Learning Inventory (BALLI) was distributed to all the 254 form four students in Lahat Datu but only 193 students responded. This survey instrument consists of 34 items. Results of a One-way ANOVA test showed a significant difference among ethnic groups on motivation and expectation in learning English. Bajau students showed the highest motivation and expectation in learning English, followed by other ethnic minorities compared to Kadazan/Dusun students. Although participants scored high for motivation and expectation to learn English, they perceived that English is a difficult language to acquire. BALLI is used to identify the misconceptions or beliefs held among learners and find ways to reduce the negative impacts in learning English.
\end{abstract}

\section{Background of study}

Beliefs about language learning refers to language learners' preconceived ideas or notions on a variety of issues related to second or foreign language learning (Horwitz, 1987). Christison and Krahnke (1986) stress that studies of learner belief and attitude offer useful insights into language learning. What learners believe about learning is frequently influenced by the context in which they learn. Horwitz $(1987,1988)$ finds that learners' beliefs about language learning are influenced by their previous language learning experiences as well as cultural background. This is because language is able to express various aspects of culture (Kramsch, 1998). The heterogeneous and culturally diverse ethnic groups in Sabah have coloured the uniqueness of learning English in Sabah. Sabah is known as the Land below the Wind and has gained independence through the formation of the Federation of Malaysia in 1963. Bajau is the second largest ethnic group in Sabah after the Kadazan-Dusun among 18 other major ethnic groups. Land Bajaus have mainly settled down at the west coast of Sabah while Sea Bajaus have settled along the east coast of Sabah.

Chitravelu, Sithamparam and Teh (1995) in the book entitled "ELT Methodology" listed down many reasons why Malaysians learn English. The reasons include the necessity to pass exams, access to educational opportunities, career needs, status and friendship. Hence, every act we perform as a teacher is influenced by what we believe a teacher is, what learning is, what we think we ought to be teaching and how best this can be achieved. When we examine carefully the strategies listed by the Ministry of Education on Upholding the Malay Language and Strengthening the Command of English (MBMMBI), on the National Educationl Philosophy, on the practical principles suggested by Chitravelu, Sithamparam and Teh about teaching English approaches, we can notice that there are quite similar trends with the Beliefs about Language Learning Inventory (BALLI) pioneered by Horwitz (1985). 


\section{Problem Statement}

For almost three decades, the role of learners' language learning beliefs and how these beliefs affect language learners' learning experiences have been an issue (Ariogul, Unal\&Onursal, 2009). Due to this reason, researchers and educators have made a shift of research interest in language learning from teacher-centred learning to learner-centred learning. This shift is to find out the dynamics of learning from the learners' perspectives.

The deeply held beliefs that most learners appear to have about second language learning have received a lot of attention by researchers and educators. One finding of this study is that preconceived aptitude and notions that learners hold could negatively affect the way they view the language learning experiences (Ariogul et al., 2009). Some of these misconceptions should be taken very seriously (Altan, 2006) particularly for those who are educating learners about English as a second language. Recently, Sabah recorded a 63.06\% passing rate for the English paper in PMR (Malaysian Lower Secondary Assessment) for the year 2011, surpassing its target of $61.77 \%$ compared to the year 2010. But the level of performance is lower than the national level of 72.8\% (Sabah New Times, 2011, 23 December).

\section{Literature Review}

The lack of English language proficiency remains a perennial challenge for both teachers and learners especially in the context of learning English as second language (Manzo, 1999; Silvia, 2001). This perennial problem can affect learners' academic and career advancement. English represents different things to different people. For some, it corresponds to the language of English literature, for others, it is the language of the English-speaking world. Some associate it with the language of colonialism. Some see English simply as a means of doing business and making money while others perceive English as tool for social networking. (Chitravelu et al, 1995).

Abdul Aziz Ismail in Compendium: A Handbook for IELT Teachers, Volume I expressed that the English language has played a significant role in the lives of Malaysians. Prior to the 1970's, English was not only the medium of instruction in the elite schools, but also the undisputed key to academic, social and economic mobility for school leavers (Compendium, 1991). Today, it is not only often described as 'a strong second language', but in reality, a compulsory foreign language to some primary and secondary schools. The Curriculum Specification (2003, page 1) spells out the aims of KBSM English language education by the Ministry of Education as:

"English is taught in both the primary and secondary schools in Malaysia. Its position is that of a second language. It is a means of communication in certain everyday activities and certain job situations. ...It also provides an additional means of access to academic, professional, and recreational materials".

The expression of second language is used in the specifications in a non-technical sense. Firstly, English occupies the position as the 'second most important language' in Malaysia. Secondly, it refers to the fact that for many students, it is the first foreign language learned after the mother tongue (Chitravelu, Sithamparam \& Teh, 1995). The first attempt to systematically investigate those beliefs started with Horwitz's studies $(1985,1988,1999)$. Research on the beliefs about language learning since Horwitz's pioneering study in 1985 have indicated that some of these beliefs are detrimental to their learning (Peacock, 2001). The factors that are influencing these beliefs may be due to learners' use of mother tongues, social context, religious beliefs, ethnics and gender differences.

The deeply held beliefs that most students appear to have about learning English as a second language have received a lot of attention in the past three decades (Peacock, 2001). Numerous quantitative studies using the beliefs about language learning inventory since Horwitz's (1985) ground-breaking study have been conducted, but little research had been done qualitatively. As Manfred (2008) suggested in his study, triangulation of the sources of data such as interviews, diaries or even observations allow for a more comprehension picture on students' beliefs about language learning inventory. Furthermore, there is a dearth of studies in rural schools. Educators have also recognised the importance of learners' contribution in the classroom and have sought to find ways to understand their beliefs from their points of view. But previous research on beliefs about language learning has focused on the tertiary level for learners and teachers (Sakui \& Gaies, 1999),

\subsection{Definition and Concept}

Beliefs as defined by Victori and Lockhart (1995) are the factors that influence learning, the nature of language learning and the general assumptions that learners have about themselves as learners. It is an implicit theory. Understanding learner beliefs in this context is essential (Bernat \& Lloyd, 2007) since learners who have successfully developed the beliefs about language learning processes, the skills and abilities to learn English and effective used of learning strategies are more successful in learning the language.

Cotterall (1999) claimed that, beliefs play a decisive role in language learners' successes, failures and experiences. One's belief systems, social cognitions and metacognitions are a driving force for intellectual performance. It is a selfconstructed representational system. As a result, information of these beliefs enable teachers to make more informed choices about teaching (Bernat \& Gvozdenko, 2005), and more sensitive approaches to the organization of learning opportunities (Cotterall, 1999).

Pintrich and De Groot (1990) argue that learners who show higher degrees of perseverance in their work usually regard their studies as important or interesting. Thus, knowledge of learners' beliefs about learning English as second language may provide teachers with a better understanding of learners' expectation of, commitment to, success in and satisfaction with their English language learning in the classrooms (Horwitz, 1988). 


\subsection{Beliefs and Ethnic Groups}

Numerous studies have been carried out in the past using beliefs about language learning inventory (BALLI) all over the globe, such as research into the effects of study-aboard programmes on students' learning of English and their change of beliefs after the programme in Japan (Takana \& Ellis, 2003), and the investigation on the beliefs of preservice English foreign language teachers in Turkey (Tercanlioglu, 2005). However, only a few studies have been found, like Nikitina and Furuoka (2006), researching the language learning beliefs of foreign language learners who grew up in a multi-lingual surrounding and have had an extensive language learning experience in University Malaysia Sabah. In another study, Bernat (2006) compared her results of the study on 262 English for Academic Purposes language learners at an Australian university with Siebert (2003) on 156 English for Academic Purposes language learners at an American university. The results showed that beliefs about language learning reported by both study groups were similar in all categories.

\subsection{Learners' Beliefs about Language Learning}

Learners' beliefs, on the other hand, which contribute to attitude and motivation, may affect language learning. Riley (2009) concludes that significant differences were found in student response to almost a quarter of the items on the questionnaire after the nine-month period of English study. It is therefore useful to investigate learner beliefs, and to make informed decisions about approaches for teaching English. Tanaka and Ellis (2003) studied about a 15-week study-aboard programme for Japanese university students and examined changes in the students' beliefs about language learning and their English proficiency. The results showed statistically significant changes in the students' beliefs before and after the programme but no significant correlations between beliefs and the scores of English.

Furthermore, Tsygalniotsky (2007) in his study on the participants learning Japanese pointed out that beliefs about difficulty did not correlate with learner's background factors and proficiency factors. He suggested that future research of relationships between other components of Japanese language and the beliefs about difficulty. Beliefs need to be conducted in order to understand how beliefs about difficulty affect proficiency. Borbala Rieger (2009) carried out a study at a Hungarian university and found out a number of significant differences based on the gender and target language of respondents. With regard to gender, statistically significant differences also arose in relation to the perceived importance of some language learning approaches or techniques.

This study identifies the differences between the three ethnic groups, namely, Kadazans/Dusuns, Bajaus, and other minority ethnic groups on the beliefs about learning English as a second language based on the five variables, that is, language aptitude, language learning difficulty, language learning and communicating strategies, nature of language learning as well as learning motivation and expectation. In the context of this study, other minority ethnic groups include Bisaya, Murut, Lotud and Rungus.

\subsection{English Language Learning Aptitude}

Wong (2010) examined a group of pre-service teachers by using frequency statistics. She generalised that pre-service teachers recognised the existence of foreign language aptitude and place strong emphasis on excellent pronunciation, vocabulary acquisition and the beliefs of practice. Also, target language seems to affect how learners perceive the difficulty of the foreign language they are studying and the importance they attach to some approaches towards language learning. It seems premature to conclude that beliefs about language learning vary by contextual setting. Rather, they are due to the effects of individual's complex metacognitive structure that is responsible for the nature and strength of these beliefs (Rieger, 2009).

\subsection{The Difficulty of Language Learning}

In 1988, Horwitz stated that student judgements about the difficulty of language learning are critical to the development of students' expectations for and commitment to language learning. If they underestimate the difficulty of the task, they are likely to become frustrated when they do not make the expected progress. On the other hand, a belief that it will take ten years or more to learn a language could be discouraging and cause them to make only minimal efforts because of the long duration of time. Moreover, extensive researches have used beliefs about language learning inventory in mostly monolingual countries and at tertiary level to investigate beliefs in various language learning contexts. Tsygalnisky (2007), for example, explored how Japanese language learners' beliefs about language learning affect the language learning strategies and its relationship on beliefs about language learning difficulties. The finding of the study showed beliefs on the difficulty in learning a language correlated positively to the proficiency factor.

\subsection{Learning and Communicating Strategies}

Likewise, Chang and Shen (2005) applied BALLI and the strategy inventory for language learning (SILL) to examine a sample of 250 Taiwanese remote junior high school English foreign language (EFL) learners and discovered that learner's variable influenced language learning beliefs and strategies in many uneven ways. There are eight statements under this domain. Learning and communicating strategies are the approaches applied by the learners in order to master the language. In this study, students are asked to give their opinions on the strategies that they use such as how they deal with pronunciation, mistakes, the use of audio-visual aids and the opportunity they have to practise the language they are learning.

\subsection{The Nature of Language Learning}

Tercanlioglu (2005) used the BALLI to study the language learning beliefs of a group of pre-service English as foreign language (EFL) teachers with regard to gender. The researcher found out there was no significant differences among 
males' and females' beliefs. There are six items under this category. The nature of language learning is the supportive environment given to encourage the learners to expose the language. In this study, the more exposure the students have in learning the language, the more likely they will master the language. A higher score in this section indicates that students have better supportive surroundings in learning this language.

\subsection{Motivation and Expectation}

Ariogul, Unal and Onursal (2009) studied a group of Turkish university students and found out that although French language learners had more positive expectations in language learning, while all the other three groups (English, German and French) held certain beliefs that would be detrimental to their long-term language learning.

In addition, Tercanlioglu (2005) explored pre-service EFL teachers' beliefs and relationships between beliefs and gender. This may influence what and how they teach within the Turkish context. In the result, she found out that motivations and expectation to learn is the most important belief. It also provided insights on the interrelationship between belief factors and there were no significant relationships between genders on the belief factors. There are six statements under this theme. Motivation and expectation is the belief that the learners are likely to learn the language successfully. In this study, students were asked to give their opinions on the extent of the possibility they will acquire the language. A higher score in this category indicates that students have higher hopes that they can master the language well.

\section{Methodology}

The population is six government secondary schools in Lahad Datu District of Sabah. In this district, there are four secondary schools in the Tungku Zone. There are 3,142 students in this zone. The sample size encompassed all the form four students for the year 2011 in one of the four secondary schools in Tungku Zone. 254 form four students are selected from this school to reduce sampling error (Creswell, 2003). In this study, the researcher managed to get 193 form four students in one of the rural secondary schools of Lahad Datu District in Sabah, Malaysia. Among the 193 students, 108 (56\%) students were from the Bajau ethnic group, 26 (13.5\%) are Dusun/Kadazan and 59 (30.6\%) from other minor ethnic groups.

\subsection{Instrument}

Beliefs about Language Learning Inventory (BALLI) was developed by Horwitz in 1985 . The 34 items to investigate the beliefs about learning English as second language was categorised into five themes namely English language aptitude with 9 items(26.5); the difficulty of language learning with 5 items (14.7\%); learning and communicating strategies with 8 items (23.5\%); the nature of language learning, with 6 items (17.6\%) and motivation including expectation with 6 items (17.6\%). BALLI utilizes a five-point Likert-scale ranging from answers indicating ' 0 ' as 'strongly disagree' to ' 5 ' as 'strongly agree'. The researcher has modified it into a six-point Likert-scale due to the mostly undecided responses during the pilot study. Students are asked to read a statement and decide if they: (0) strongly disagree, (1) disagree, (2), slightly disagree, (3) slightly agree, (4) agree, or (5) strongly agree.

\section{Findings}

Table 4.1 shows the mean scores of the students in Beliefs about learning English as a second language among form four students. As a whole, students had the highest mean $(\mathrm{M}=4.63, \mathrm{SD}=0.31)$ for motivation and expectation, followed by nature of language learning $(M=4.15, S D=0.34)$, language aptitude $(M=3.52, S D=0.80)$ and difficulty of language learning $(\mathrm{M}=0.79, \mathrm{SD}=0.59)$. The mean of difficulty of language learning is lowest when compared with the other four variables.

Table 4.1 Descriptive Statistics on Independent Variables and Dependent Variables

\begin{tabular}{lcc}
\hline Dependent Variables & $\mathrm{M}$ & $\mathrm{SD}$ \\
\hline Motivation and expectation & 4.63 & .31 \\
Language aptitude & 3.52 & .80 \\
Learning and communicating strategies & 3.16 & .33 \\
Nature of language learning & 4.15 & .34 \\
Difficulty of language learning & 0.79 & .59 \\
\hline
\end{tabular}

Most of the Dusun/Kadazan $(\mathrm{M}=3.26, \mathrm{SD}=.29)$ students believe that mistakes in English should be corrected immediately and that it is important to repeat and practice a lot if they wish to master the language. A vast majority of Bajaus $(\mathrm{M}=3.06, \mathrm{SD}=.32)$ have the same opinion that the most important part of learning English is learning new words and grammar.

A significant portion among the entire ethnic groups $(\mathrm{M}=4.57, \mathrm{SD}=.28)$ agree that it is important to speak English, that they would like to master the language and they believe that one day, they can learn English very well. A large majority of respondents believe that they would like to learn English so that they can communicate with Englishspeakers and with their friends. 
Table 4.2 Descriptive Analysis on Ethnic with Beliefs about Language Learning Inventory

\begin{tabular}{llll}
\hline Themes & \multicolumn{1}{c}{ Ethnic } & M & SD \\
\hline Language aptitude & Bajau & 3.22 & .82 \\
& Dusun/Kadazan & 3.13 & .90 \\
& Others & 3.09 & .74 \\
\hline Difficulty of language learning & Bajau & 1.25 & .60 \\
& Dusun/Kadazan & 1.23 & .54 \\
\hline Learning and communicating strategies & Others & 1.39 & .59 \\
& Bajau & 3.16 & .34 \\
\hline Nature of language learning & Dusun/Kadazan & 3.26 & .29 \\
& Others & 3.12 & .35 \\
\hline Motivation and expectation & Bajau & 3.06 & .32 \\
& Dusun/Kadazan & 2.89 & .30 \\
& Others & 2.99 & .38 \\
\hline
\end{tabular}

\subsection{Ethnicity on the beliefs about learning English as a second language}

In English language aptitude (Table 4.3), Bajau students $(\mathrm{M}=1.49, \mathrm{SD}=1.37)$ strongly disagreed that it is easier for someone who already speaks English to learn another one followed by partially disagree by Dusun/Kadazan students $(\mathrm{M}=2.12, \mathrm{SD}=1.14)$ but other minority ethnic groups agreed with item number four $(\mathrm{M}=3.97, \mathrm{SD}=1.41)$. On the contrary, other minority ethnics believed that people who are good at mathematics or science are poor at learning English $(\mathrm{M}=.92, \mathrm{SD}=1.26)$. Dusun/Kadazan students slightly disagreed $(\mathrm{M}=1.50, \mathrm{SD}=1.73)$ but for Bajau students, they came to the same agreement with statement number five $(\mathrm{M}=4.43, \mathrm{SD}=.66)$.

Table 4.3 Ethnicity and Language Learning Aptitude

\begin{tabular}{|c|c|c|c|c|c|}
\hline No & Item & Ethnic & $\mathrm{n}$ & M & SD \\
\hline \multirow[t]{3}{*}{1} & \multirow[t]{3}{*}{ Children learn English faster than adults. } & Bajau & 108 & 4.37 & .65 \\
\hline & & Dusun/Kadazan & 26 & 4.35 & .63 \\
\hline & & Others & 59 & 4.32 & .71 \\
\hline \multirow[t]{3}{*}{2} & \multirow{3}{*}{$\begin{array}{l}\text { Some people have special ability for learning } \\
\text { English. }\end{array}$} & Male Bajau & 108 & 3.10 & 1.64 \\
\hline & & Dusun/Kadazan & 26 & 3.54 & 1.36 \\
\hline & & Others & 59 & 3.05 & 1.53 \\
\hline \multirow[t]{3}{*}{4} & \multirow{3}{*}{$\begin{array}{l}\text { It is easier for someone who already speaks } \\
\text { English to learn another one. }\end{array}$} & Bajau & 108 & 1.49 & 1.37 \\
\hline & & Dusun/Kadazan & 26 & 2.12 & 1.14 \\
\hline & & Others & 59 & 3.97 & 1.41 \\
\hline \multirow[t]{3}{*}{5} & \multirow{3}{*}{$\begin{array}{l}\text { People who are good at mathematics or } \\
\text { science are very good at learning English. }\end{array}$} & Bajau & 108 & 4.43 & .66 \\
\hline & & Dusun/Kadazan & 26 & 1.50 & 1.73 \\
\hline & & Others & 59 & .92 & 1.26 \\
\hline \multirow[t]{3}{*}{6} & \multirow[t]{3}{*}{ Girls learn English faster than boys. } & Bajau & 108 & 2.56 & 1.96 \\
\hline & & Dusun/Kadazan & 26 & 3.08 & 1.94 \\
\hline & & Others & 59 & 2.88 & 1.98 \\
\hline \multirow[t]{3}{*}{7} & \multirow{3}{*}{$\begin{array}{l}\text { People who speak more than one language are } \\
\text { very intelligent. }\end{array}$} & Bajau & 108 & 2.99 & 1.80 \\
\hline & & Dusun/Kadazan & 26 & 3.31 & 1.46 \\
\hline & & Others & 59 & 2.90 & 1.78 \\
\hline \multirow[t]{3}{*}{8} & \multirow[t]{3}{*}{ Everyone can learn to speak English. } & Bajau & 108 & 4.15 & 1.29 \\
\hline & & Dusun/Kadazan & 26 & 4.15 & 1.29 \\
\hline & & Others & 59 & 4.36 & 1.16 \\
\hline \multirow[t]{3}{*}{9} & \multirow[t]{3}{*}{ I have a special ability for learning English. } & Bajau & 108 & 2.66 & 1.91 \\
\hline & & Dusun/Kadazan & 26 & 2.96 & 1.99 \\
\hline & & Others & 59 & 2.32 & 1.82 \\
\hline
\end{tabular}


From table 4.4, all ethnic groups perceived English is not an easy language to attain with Dusun/Kadazan $(\mathrm{M}=.85$, SD $=.97)$, followed by Bajau $(\mathrm{M}=1.18, \mathrm{SD}=1.03)$ and others $(\mathrm{M}=1.24, \mathrm{SD}=1.02)$. They also accepted item number twelve as true that learning reading and writing skills is more difficult than learning speaking skills. Bajau students strongly disagreed with this statement $(\mathrm{M}=.82, \mathrm{SD}=.84)$, followed by Dusun/Kadazan students $(\mathrm{M}=.88, \mathrm{SD}=.95)$ and others $(\mathrm{M}=1.03, \mathrm{SD}=.89)$.

Table 4.4 Ethnicity and Language Learning Difficulty

\begin{tabular}{lllrrr}
\hline No & Item & Ethnic & \multicolumn{1}{c}{$\mathrm{n}$} & \multicolumn{1}{c}{$\mathrm{M}$} & \multicolumn{1}{c}{ SD } \\
\hline 10 & English is easier to learn than other languages. & Bajau & 108 & 1.18 & 1.03 \\
& & Dusun/Kadazan & 26 & .85 & .97 \\
& & Others & 59 & 1.24 & 1.02 \\
\hline \multirow{2}{*}{12} & Learning reading and writing is easier than & Bajau & 108 & .82 & .84 \\
& speaking. & Dusun/Kadazan & 26 & .88 & .95 \\
& & Others & 59 & 1.03 & .89 \\
\hline 13 & English is a very easy language to learn. & Bajau & 108 & 1.54 & 1.36 \\
& & Dusun/Kadazan & 26 & 1.38 & 1.50 \\
& & Others & 59 & 1.63 & 1.38 \\
\hline 14 & If I spent one hour a day learning English, I & Bajau & 108 & 1.48 & 1.76 \\
& can speak English very well within a year. & Dusun/Kadazan & 26 & 1.81 & 2.02 \\
& & Others & 59 & 1.64 & 1.79 \\
\hline
\end{tabular}

For English language learning and communicating strategies used by the respondents (Table 4.5), all form four secondary students had the same opinion that it is important to repeat and practice a lot if they wish to master English. The highest mean score of $4.73(\mathrm{SD}=.53)$ was from Dusun/Kadazan students, followed closely by Bajau students $(\mathrm{M}=$ $4.41, \mathrm{SD}=.67)$ and others $(\mathrm{M}=4.19, \mathrm{SD}=.78)$.

Table 4.5 Ethnic and Language Learning, Communicating Strategies

\begin{tabular}{|c|c|c|c|c|c|}
\hline No & Item & Gender & $\mathrm{n}$ & $\mathrm{M}$ & SD \\
\hline \multirow[t]{3}{*}{15} & \multirow{3}{*}{$\begin{array}{l}\text { It is important to speak English with } \\
\text { excellent pronunciation. }\end{array}$} & Bajau & 108 & 1.15 & 1.08 \\
\hline & & Dusun/Kadazan & 26 & 1.08 & .85 \\
\hline & & Others & 59 & 1.17 & 1.10 \\
\hline \multirow[t]{3}{*}{16} & \multirow{3}{*}{$\begin{array}{l}\text { You can speak English only when you can } \\
\text { say it correctly. }\end{array}$} & Bajau & 108 & 1.21 & .89 \\
\hline & & Dusun/Kadazan & 26 & 1.42 & .86 \\
\hline & & Others & 59 & 1.02 & .86 \\
\hline \multirow[t]{3}{*}{17} & \multirow[t]{3}{*}{ It is important to repeat and practice a lot. } & Bajau & 108 & 4.41 & .67 \\
\hline & & Dusun/Kadazan & 26 & 4.73 & .53 \\
\hline & & Others & 59 & 4.19 & .78 \\
\hline \multirow[t]{3}{*}{18} & \multirow{3}{*}{$\begin{array}{l}\text { Mistakes in English should be corrected } \\
\text { immediately. }\end{array}$} & Bajau & 108 & 4.42 & .71 \\
\hline & & Dusun/Kadazan & 26 & 4.46 & .58 \\
\hline & & Others & 59 & 4.36 & .76 \\
\hline \multirow[t]{3}{*}{19} & \multirow{3}{*}{$\begin{array}{l}\text { It is important to practice English with } \\
\text { computer and CDs. }\end{array}$} & Bajau & 108 & 4.37 & .80 \\
\hline & & Dusun/Kadazan & 26 & 4.42 & .58 \\
\hline & & Others & 59 & 4.47 & .70 \\
\hline \multirow[t]{3}{*}{21} & \multirow{3}{*}{$\begin{array}{l}\text { It's OK to guess if you don't know a word } \\
\text { in English. }\end{array}$} & Bajau & 108 & 3.43 & .85 \\
\hline & & Dusun/Kadazan & 26 & 3.42 & .81 \\
\hline & & Others & 59 & 3.54 & .73 \\
\hline
\end{tabular}

Table 4.6 showed that all students agreed enormously that the most important part of learning English is learning new words. Bajau students had the highest mean scores $(\mathrm{M}=4.57, \mathrm{SD}=.60)$, followed by other minority ethnic groupss $(\mathrm{M}$ $=4.49, \mathrm{SD}=.70)$ and Dusun/Kadazan $(\mathrm{M}=4.35, \mathrm{SD}=.69)$. Learning grammar is also perceived to be equally 
important. The highest mean scores were for the Bajau students $(\mathrm{M}=4.59, \mathrm{SD}=.67)$, followed by the other ethnic groups $(\mathrm{M}=4.49, \mathrm{SD}=.63)$ and Dusuns/Kadazans $(\mathrm{M}=4.42, \mathrm{SD}=.64)$.

Table 4.6 Ethnicity and Nature of Language Learning

\begin{tabular}{lllrrr}
\hline No & Item & Gender & $\mathrm{n}$ & $\mathrm{M}$ & $\mathrm{SD}$ \\
\hline 23 & To learn English is to know English- & Bajau & 108 & .78 & .93 \\
& speaker's cultures well. & Dusun/Kadazan & 26 & .73 & .67 \\
& & Others & 59 & .56 & .77 \\
\hline 24 & You learn English best when you are in & Bajau & 108 & .77 & .83 \\
& England. & Dusun/Kadazan & 26 & .35 & .49 \\
& & Others & 59 & 1.03 & 1.05 \\
\hline 25 & The most important part of learning & Bajau & 108 & 4.57 & .60 \\
& English is learning new words. & Dusun/Kadazan & 26 & 4.35 & .69 \\
& & Others & 59 & 4.49 & .70 \\
\hline \multirow{2}{*}{26} & The most important part of learning & Bajau & 108 & 4.59 & .67 \\
& English is learning grammar. & Dusun/Kadazan & 26 & 4.42 & .64 \\
& & Others & 59 & 4.49 & .63 \\
\hline 27 & Learning English is different than learning & Bajau & 108 & 4.59 & .60 \\
& other academic subjects. & Dusun/Kadazan & 26 & 4.62 & .57 \\
& & Others & 59 & 4.37 & 1.00 \\
\hline
\end{tabular}

The responses from this study shows that even though English is difficult for them, they have high levels of motivation and great expectation in mastering it (Table 4.7). All of them deemed that they will have better job opportunities in future, with Bajaus having the highest mean scores $(\mathrm{M}=4.70, \mathrm{SD}=.55)$, followed closely by the other ethnic groups $(\mathrm{M}=4.69, \mathrm{SD}=.50)$ and Dusuns/Kadazans $(\mathrm{M}=4.46, \mathrm{SD}=.76)$. This perception is closely connected to item number 33 , that is, to learn English well. Bajau students wanted to learn English well $(\mathrm{M}=4.67, \mathrm{SD}=.53)$, followed by other minority ethnic students $(\mathrm{M}=4.56, \mathrm{SD}=.65)$ and Dusun or Kadazan students $(\mathrm{M}=4.27, \mathrm{SD}=.72)$.

Table 4.7 Ethnics and Language Learning Motivation and Expectation

\begin{tabular}{|c|c|c|c|c|c|}
\hline No & Item & Gender & $\mathrm{n}$ & M & SD \\
\hline \multirow[t]{3}{*}{29} & \multirow{3}{*}{$\begin{array}{l}\text { Malaysians think that it is important to speak } \\
\text { English. }\end{array}$} & Bajau & 108 & 4.62 & .60 \\
\hline & & Dusun/Kadazan & 26 & 4.42 & .70 \\
\hline & & Others & 59 & 4.34 & .80 \\
\hline \multirow[t]{3}{*}{30} & \multirow{3}{*}{$\begin{array}{l}\text { I would like to learn English so that I can talk } \\
\text { to English-speakers. }\end{array}$} & Bajau & 108 & 4.50 & .59 \\
\hline & & Dusun/Kadazan & 26 & 4.35 & .56 \\
\hline & & Others & 59 & 4.47 & .63 \\
\hline \multirow[t]{3}{*}{31} & \multirow{3}{*}{$\begin{array}{l}\text { If I learn English very well, I will have better } \\
\text { job opportunities. }\end{array}$} & Bajau & 108 & 4.70 & .55 \\
\hline & & Dusun/Kadazan & 26 & 4.46 & .76 \\
\hline & & Others & 59 & 4.69 & .50 \\
\hline \multirow[t]{3}{*}{32} & \multirow{3}{*}{$\begin{array}{l}\text { I believe that I will learn to speak English very } \\
\text { well. }\end{array}$} & Bajau & 108 & 4.43 & .62 \\
\hline & & Dusun/Kadazan & 26 & 4.35 & .63 \\
\hline & & Others & 59 & 4.46 & .63 \\
\hline \multirow[t]{3}{*}{33} & \multirow[t]{3}{*}{ I want to learn English well. } & Bajau & 108 & 4.67 & .53 \\
\hline & & Dusun/Kadazan & 26 & 4.27 & .72 \\
\hline & & Others & 59 & 4.56 & .65 \\
\hline \multirow[t]{3}{*}{34} & \multirow[t]{3}{*}{ I would like to speak English with my friends. } & Bajau & 108 & 4.51 & .69 \\
\hline & & Dusun/Kadazan & 26 & 4.54 & .58 \\
\hline & & Others & 59 & 4.53 & .60 \\
\hline
\end{tabular}




\section{Discussion}

The Beliefs about Language Learning Inventory (BALLI) has been categorised by Horwitz (1987) into five different domains, as mentioned earlier: English Language Aptitude, The Difficulty of Language Learning, Learning and Communicating Strategies, The Nature of Language Learning, Motivation and Expectations. As a whole, the difference between the three ethnic groups and Belief about English language learning among the form four students in this rural secondary school showed almost no significant differences except two items with marginal significant differences. The rest of the domains obtained no significant differences among ethnic groups.

In general, all ethnic groups scored the highest mean on the five items of motivation and expectations domain. It was similar to the study conducted by Tercanlioglu in 2005. Participants scored the highest mean for the motivation and expectations to learn a language. The result signified that Dusun, Kadazan and other ethnic groups have higher motivation and expectations than Bajau students. Correspondingly, Rifkin (2000) performed a large sample study across various institutions in the America and revealed that, students' beliefs about language learning deferred by contextual setting.

Most Bajau students disagreed that it is easier for someone who already spoke English to learn another language. They agreed that people who are good at mathematics or science are very good at learning English. From these two statements, the findings are similar with what had been concluded by Yang (1999) who stated culture and ethnicity play a role in shaping students' beliefs. This implies that authentic assessment should be used among students with different cultural background and learning styles.

The BALLI seems to have proven its usefulness in the elicitation and comparison of many learners' beliefs about language learning. If any learners have any beliefs about language learning that may negatively affect their future learning, it is important for English teachers to consider changing them (Peacock, 2001). Furthermore, other factors such as experience of learning English, academic performance of learners and different educational practices used are worth to investigate in future study (Tercanlioglu, 2005). With the use of data collecting instruments such as BALLI, teachers should also encourage guided reflection among learners. Let them think aloud and share the success and failure in learning the language (Peacock, 2001).

\section{Implication}

According to the results of present study, pedagogical implications are provided. Firstly, by the use of BALLI, teachers can trace back to their learners' characteristics especially the below average achievers in English. Secondly, to understand the unique sociolinguistic roles (Manfred, 2008) of English in Malaysia, which has been mentioned earlier, the status of English in urban areas differ from remote areas and lastly, the lack of exposure of English for most people in remote areas of Sabah. There is a positive relationship between students who are good at mathematics or science and good at learning English. This could be due to the effect of Teaching and Learning Science and Mathematics in English (PPSMI) since 2003. However, it will be replaced by Upholding the Malay Language and Strengthening the Command of English (MBMMBI) after soft-landing PPSMI in 2012. This paper had addressed the aims of the current study by identifying aspects of learners' beliefs in the Malaysian context and discussing them in the light of current literature, thus filling a gap in locally situated research. The results of this study present only a static, cross-sectional view of learners' beliefs. The extent to which learners' beliefs are variable over time, from person to person, and setting to setting needs further exploration.

\section{References}

Altan, M.Z. (2006). Beliefs about language learning of foreign language-major university students. Australian Journal of Teachers Education, 31(2), $45-52$. Ariogul, S., Unal, D. C., \& Onursal, I. (2009). Foreign language learners' beliefs about language learning: a study on Turkish university students. Procedia Social and Behavioural Sciences, 1, 1500-1506.

Bernat, E. \& Gvozdenko, M. (2005). Beliefs about language learning: Current knowledge, pedagogical implications and new research directions. TESLJ-EJ, $9(1)$.

Bernat, E. (2006). Assessing EAP learners' beliefs about language learning in the Australian context. Asian EFL Journal, 8(2), 202-227.

Bernat, E. \& Lloyd, R. (2007). Exploring the gender effect on EFL learners'beliefs about language learning. Austrialian Journal of Education \& Devolopment Psychology, 7, 79-91.

Chang, C. Y. \& Shen, M. C. (2007). The effects of beliefs about language learning and learning strategy use of junior high school EFL learners in remote districts. Research in Higher Education Journal, 1-8.

Chitravelu, N., Sithamparam, S., \& Teh, S. C. (1995). ELT methodology: Principles and practice. Shah Alam: Penerbit Fajar Bakti Sdn. Bhd.

Christison, M. \& Krahnke, K. (1986). Student perceptions of academic language study. TESOL Quarterly, 20, 61-81

Cotterall, S. (1999). Key variables in language learning: What do learners believe about them? System, 27, 493-513.

Creswell, J. W. (2003). Research design: Qualitative and mixed methods approaches. 
SAGE. USA: Thousand Oaks.

Horwitz, E. K. (1985). Using student beliefs about language learning and teaching in the foreign language methods course. Foreign Language Annals, 18(4), 333 340 .

Horwitz, E. K. (1987). Surveying student beliefs about language learning. In A. Wenden and J. Robin. Learner strategies in language learning. Prentice Hall, Englewood Cliffs, NJ.

Horwitz, E. K. (1988). The beliefs about language learning of beginning university foreign language students. Modern Language Journal, $72(3), 283-294$. Horwitz, E. K. (1999). Cultural and situational influences on foreign language leanrers' beliefs about language learning: a review of BALLI studies. System, 27(4), 555-576.

Kramsch C. (1998). Language and Culture. Oxford: Oxford University Press. Manfred, W. M. (2008). Beliefs about language learning of Chinese ESL learners undertaking vocational education in Hong Kong. New Horizons in Education, $56(2), 1-16$.

Manzo, K. (1999). U. S. students lack writing proficiency. Education Week, 6 October,

$1 \& 18$.

M B M B I to be implemented in 2012. (2010, June 18). The Star. pp. 2 Ministry of Education of Malaysia. (1991). Compendium: A handbook for ELT

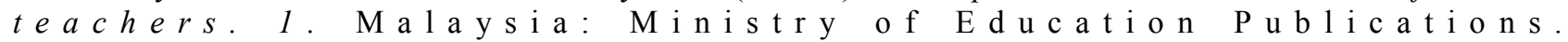
Nikitina, L. \& Furuoka, F. (2006). Re-examining Horwitz's beliefs about language learning inventory (B ALLI) in the Malaysian context. Electronic Journal of Foreign Langauge Teaching, 3(2), 209-219.

Peacock, M. (2001). Pre-service ESL teachers' beliefs about second language learning: a longitudinal study. System, 29, 177-195.

Pintrich, P. R. \& De Groot, E. V. (1990). Motivational and self-regulated learning components of classroom academic performance. Journal of Education Psychology, 82(1), 33-40.

Rieger, B. (2009). Hungarian university students' beliefs about language learning: a questionnaire study. WoPaLP, 3, 97-112.

Rifkin, B. (2000). Revising beliefs about foreign language learning. Foreign Language Annuals, 33(4), 394-420.

Riley, P. A. (2009). Shift in beliefs about second language learning. RELC Journal: A Journal of Langauge Teaching and Research, 40(1), 102-124.

Sakui, K. \& Gaies, S. J. (1999). Investigating Japanese learners' beliefs about language learning. System, 27, 473-492.

Siebert, L. L. (2003). Student and teacher beliefs about language learning. The ORTESOL Journal, 21, 7-39.

Silvia, T. (2001). Toward an understanding of the distinct nature of L2 writing: The ESL research and its implications. In T. Silva \& P. K. Matsuda (Eds.), Landmark Essays on ESL Writing, ( p p. 191-203). Mahwah: Law re nce Erlbaum Associates, Inc.

Tanaka, K. \& Ellis, R. (2003). Study-aboard, language proficiency, and learner beliefs about language learning. JALT Journal, 25(1), 63-85.

Tercanlioglu, L. (2005). Pre-service EFL teachers' beliefs about foreign language learning and how they relate to gender. Electronic Journal of Research in Education Psychology, 3(1), 145-162.

Tsygalnisky, E. (2007). Beliefs about difficulty in language learning and learners' factors. Japanese Language Journal, 26, 83-94.

Victori, M. \& Lockhart, W. (1995). Enhancing metacognition in self-directed language learning. System, 23(2), 223-234.

Wong, S. L. (2010). Beliefs about language learning: a study of Malaysian pre-service teachers. RELC Journal: A Journal of Language Teaching and Research, 41(2), 123-136.

Yang, N. D. (1999). The relationship between EFL learners' beliefs and learning strategy use. System 27(4), 515-535. 